\title{
Will climate change increase ozone depletion from low-energy-electron precipitation?
}

\author{
A. J. G. Baumgaertner ${ }^{1}$, P. Jöckel ${ }^{1,{ }^{*}}$, M. Dameris ${ }^{2}$, and P. J. Crutzen ${ }^{1}$ \\ ${ }^{1}$ Max Planck Institute for Chemistry, 55020 Mainz, Germany \\ ${ }^{2}$ Deutsches Zentrum für Luft-und Raumfahrt (DLR), Institut für Physik der Atmosphäre, Oberpfaffenhofen, \\ 82234 Weßling, Germany \\ *now at: Deutsches Zentrum für Luft-und Raumfahrt (DLR), Institut für Physik der Atmosphäre, Oberpfaffenhofen, \\ 82234 Weßling, Germany
}

Received: 16 March 2010 - Published in Atmos. Chem. Phys. Discuss.: 16 April 2010

Revised: 26 August 2010 - Accepted: 4 October 2010 - Published: 11 October 2010

\begin{abstract}
We investigate the effects of a strengthened stratospheric/mesospheric residual circulation on the transport of nitric oxide (NO) produced by energetic particle precipitation. During periods of high geomagnetic activity, energetic electron precipitation (EEP) is responsible for winter time ozone loss in the polar middle atmosphere between 1 and $6 \mathrm{hPa}$. However, as climate change is expected to increase the strength of the Brewer-Dobson circulation including extratropical downwelling, the enhancements of EEP $\mathrm{NO}_{\mathrm{x}}$ concentrations are expected to be transported to lower altitudes in extratropical regions, becoming more significant in the ozone budget. Changes in the mesospheric residual circulation are also considered. We use simulations with the chemistry climate model system EMAC to compare present day effects of EEP $\mathrm{NO}_{\mathrm{x}}$ with expected effects in a climate change scenario for the year 2100. In years of strong geomagnetic activity, similar to that observed in 2003, an additional polar ozone loss of up to $0.4 \mu \mathrm{mol} / \mathrm{mol}$ at $5 \mathrm{hPa}$ is found in the Southern Hemisphere. However, this would be approximately compensated by an ozone enhancement originating from a stronger poleward transport of ozone from lower latitudes caused by a strengthened Brewer-Dobson circulation, as well as by slower photochemical ozone loss reactions in a stratosphere cooled by risen greenhouse gas concentrations. In the Northern Hemisphere the EEP $\mathrm{NO}_{\mathrm{x}}$ effect appears to lose importance due to the different nature of the climatechange induced circulation changes.
\end{abstract}

Correspondence to:

A. J. G. Baumgaertner

(work@andreas-baumgaertner.net)

\section{Introduction}

The Earth's middle and upper atmosphere are strongly influenced by solar variability. Changes in the solar spectral irradiance as well as in the solar wind can lead to significant perturbations. Solar wind disturbances have been shown to lead to geomagnetic activity variations, which can result in magnetospheric loss of electrons (e.g. Clilverd et al., 2006). These electrons precipitate into the atmosphere at high geomagnetic latitudes where they lead to the production of $\mathrm{NO}_{\mathrm{x}}$, termed energetic electron precipitation (EEP) $\mathrm{NO}_{\mathrm{x}}$, through dissociation and ionisation processes. Downward transport in the dark polar winter can lead to significant enhancements of $\mathrm{NO}_{\mathrm{x}}$ in the stratosphere. Because $\mathrm{NO}_{\mathrm{x}}$ can catalytically destroy ozone, such $\mathrm{NO}_{\mathrm{x}}$ enhancements lead to ozone depletion in the upper stratosphere as has been shown e.g. by Callis et al. (1998), Brasseur and Solomon (2005), Jackman et al. (2008), or Baumgaertner et al. (2009). In the mesosphere, the mean meridional circulation transports air from the summer to the winter hemisphere driven by gravity wave energy and momentum deposition as well as radiative heating and cooling (Brasseur and Solomon, 2005). In the polar winter, this circulation can transport air, including EEP induced $\mathrm{NO}_{\mathrm{x}}$ enhancements, from the mesosphere into the stratosphere. In the polar stratosphere, further downward transport is controlled by the Brewer-Dobson circulation (BDC). The BDC is responsible for the meridional transport of air in the stratosphere: It mainly consists of poleward transport in the middle and upper stratosphere, with rising air in the tropics and downwelling air in the polar regions. Horizontal mixing and mixing barriers can also be important factors for the meridional distribution of trace gases.

Model studies have reported that climate change leads to a strengthening of the BDC. One of the first model predictions

Published by Copernicus Publications on behalf of the European Geosciences Union. 
of increased tropical upwelling was published by Butchart and Scaife (2001), who attributed their findings to changes in planetary wave driving. Further modelling studies of this phenomenon were conducted e.g. by Butchart et al. (2006), Butchart et al. (2010), Deckert and Dameris (2008), Garcia and Randel (2008), and Garny et al. (2009). McLandress and Shepherd (2009) also studied the BDC response to climate change at high-latitudes, and only found an increase in Arctic downwelling in winter, whereas in Antarctic spring downwelling decreased. A full picture of the mechanisms that could strengthen the BDC has not yet been established. However, there is some evidence for a strengthening of the subtropical jets due to greenhouse warming, leading to changes in the transient Rossby wave drag (T. Shepherd, personal communication, 2009). Note, however, that so far no clear evidence for an acceleration of the BDC has been found from measurements (e.g. Engel et al., 2009).

The residual circulation in the mesosphere might also be subject to changes in a modified climate. Such changes could for example be caused by modified filtering conditions for gravity waves due to circulation changes in the stratosphere. However, such effects are still under discussion. Schmidt et al. (2006) found a weakening in the meridional circulation using model simulations, but long-term radar measurements have not yet been able to unambiguously identify a trend (Baumgaertner et al., 2005; Keuer et al., 2007).

If climate change leads to a modified residual circulation in the stratosphere or mesosphere, EEP $\mathrm{NO}_{\mathrm{x}}$ and its effect on ozone could be different in the future. For example, increased downwelling at high-latitudes would transport EEP $\mathrm{NO}_{\mathrm{x}}$ to lower altitudes, where it can become more important for the ozone budget due to the availability of ozone. However, this is limited by the fact that at lower stratospheric altitudes, where lower temperatures prevail, ozone loss through $\mathrm{NO}_{\mathrm{x}}$ cycles is slower and thus less efficient.

Here, we investigate the impact of middle atmosphere circulation changes caused by increased greenhouse gas concentrations on EEP $\mathrm{NO}_{\mathrm{x}}$ and polar stratospheric ozone using the ECHAM5/MESSy Atmospheric Chemistry (EMAC) climate model. The climate change scenario SRES A2 (Nakicenovic et al., 2000), the most extreme scenario in terms of climate change, is used for the year 2100 in order to drive simulations with a stronger BDC. All simulations for present day and year-2100 conditions have repeating boundary conditions, meaning that sea surface temperatures (SST), emissions, etc. were repeated on a yearly basis to minimise interannual variability induced by these boundary conditions. The model and the model setup are described in Sect. 2, the results are discussed in Sect. 3, and conclusions are presented in Sect. 4.

\section{Model description, configuration, and setup}

\subsection{The EMAC model}

The ECHAM/MESSy Atmospheric Chemistry (EMAC) model is a numerical chemistry and climate simulation system that includes sub-models describing tropospheric and middle atmosphere processes and their interaction with oceans, land and human influences (Jöckel et al., 2006). It uses the Modular Earth Submodel System (MESSy) to link multi-institutional computer codes. The core atmospheric model is the 5th generation European Centre Hamburg general circulation model (ECHAM5, Roeckner et al., 2006). The model has been shown to consistently simulate key atmospheric tracers such as ozone (Jöckel et al., 2006), water vapour (Lelieveld et al., 2007), and lower and middle stratospheric $\mathrm{NO}_{\mathrm{y}}$ (Brühl et al., 2007). For the present study we applied EMAC (ECHAM5 version 5.3.02, MESSy version 1.8+) in the T42L90MA-resolution, i.e. with a spherical triangular truncation of T42 (corresponding to a quadratic Gaussian grid of approximately $2.8^{\circ}$ by $2.8^{\circ}$ in latitude and longitude) with 90 vertical hybrid pressure levels up to $0.01 \mathrm{hPa}$.

A list of employed submodels and related references can be found in the Appendix. The chosen chemistry scheme for the configuration of the chemistry submodel MECCA is simpler compared to the configuration in Jöckel et al. (2006). For example, the NMHC (non-methane hydrocarbon) chemistry is not treated at the same level of detail. The complete mechanism is documented in the Supplement.

\subsection{Model setup for present day simulations}

Simulations were performed for present day and for year2100 conditions. The concentrations of long-lived trace gases $\left(\mathrm{CO}_{2}, \mathrm{CH}_{4}, \mathrm{~N}_{2} \mathrm{O}\right.$, and $\mathrm{SF}_{6}$, as well as Chlorine and Bromine containing substances) are prescribed by Newtonian relaxation to present day values at the surface. Finally, present day emissions of short-lived trace gases from the surface and the boundary layer $\left(\mathrm{NO}_{\mathrm{x}}, \mathrm{NMHCs}, \mathrm{CO}, \mathrm{SO}_{2}\right.$, $\left.\mathrm{NH}_{3}\right)$, and aircraft $\left(\mathrm{NO}_{\mathrm{x}}\right)$ were applied similar to Jöckel et al. (2006). The present-day simulations use the AMIPIIb sea ice and sea surface temperature (SST) data set. The El NiñoSouthern Oscillation (ENSO) can lead to large-scale deviations of tropical SSTs from the long-term mean (see e.g. Harrison and Larkin, 1998; Enfield, 1989). During the El Niño phase, SSTs in the tropical pacific rise by more than two Kelvin, during La Niña events this area is colder than normal. Therefore, we used climatological SSTs from AMIPIIb where neither El Niño nor La Niña events occur (see the additional figures in the Supplement). 


\subsection{Model setup for year-2100 simulations}

For the simulations with year-2100 conditions in a climate change scenario, the SRES A2 scenario (IPCC Special Report on Emissions Scenarios, Nakicenovic et al., 2000) was chosen. This is the most drastic scenario, with a near doubling of $\mathrm{CO}_{2}$ resulting in a surface temperature increase of approx. $4 \mathrm{~K}$ depending on the model (IPCC, 2007). We expect that this scenario also causes the strongest circulation changes, so that effects on EEP $\mathrm{NO}_{\mathrm{x}}$ and polar ozone can be clearly distinguished from other sources of variability. The following modifications of the model setup were implemented in order to reach a climate close to that obtained from IPCC model simulations using the SRES A2 scenario.

SSTs and sea ice coverage as well as the concentrations of greenhouse gases are the most important boundary conditions that are required to simulate a future climate. SST and sea ice coverage data were taken from an IPCC AR4 simulation including an interactive ocean model, ECHAM5/MPIOM (Jungclaus, 2006). A description of MPI-OM is provided by Marsland et al. (2003), which also discusses some of the shortcomings of the model. While there is a good overall agreement between model SSTs and observations, Marsland et al. (2003) found a too weak North Atlantic poleward heat transport and differences in the observed and modelled Gulf Stream, which leads to the North Atlantic Ocean SSTs probably being too cold. Also note that in a warmer climate ECHAM5/MPI-OM shows a larger ENSO amplitude increase than most other models (Müller and Roeckner, 2008). However, these deficiencies are unlikely to adversely affect the results presented here.

Analogously to the year 2000, we have analysed the employed SSTs for El Niño or La Niña events. In the tropical pacific, anomalies are generally smaller than $1.5 \mathrm{~K}$ and do not show the typical El Niño or La Niña pattern (see the additional figures in the Supplement).

Figure 1 depicts the difference between the SSTs from the year 2099 as predicted by ECHAM5/MPI-OM (averaged over January to December 2099), and present day (averaged over the 12 climatological months from AMIPIIb, see above). Most areas show a marked increase of several Kelvin as expected. The temperature decrease in the North Atlantic is potentially linked to the poor performance of MPI-OM in this area as mentioned above.

For $\mathrm{CO}_{2}, \mathrm{CH}_{4}$, and $\mathrm{N}_{2} \mathrm{O}$ the initial concentrations as well as the prescribed surface concentrations were scaled to the expected concentrations of the trace gases in the year 2100 (SRES A2 scenario), using the information provided in Nakicenovic et al. (2000) and IPCC (2007). This yields mean surface mixing ratios of $850 \mu \mathrm{mol} / \mathrm{mol}$ for $\mathrm{CO}_{2}, 3400 \mathrm{nmol} / \mathrm{mol}$ for $\mathrm{CH}_{4}$, and $450 \mathrm{nmol} / \mathrm{mol}$ for $\mathrm{N}_{2} \mathrm{O}$.

Chlorine and bromine containing substances as well as ozone precursors were left unchanged compared to the present-day simulation. While this is unlikely to be realis-

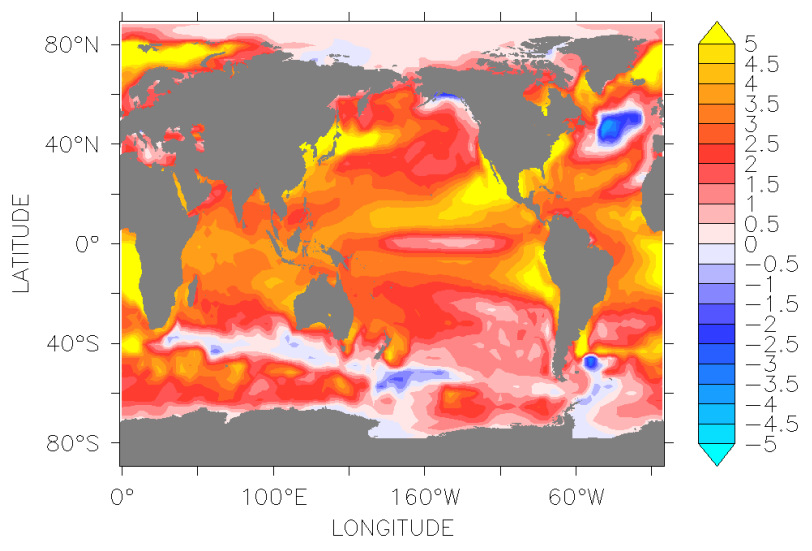

Fig. 1. Sea surface temperature difference between present day (AMIPIIb climatology) and year 2099 (IPCC AR4 model simulation, Jungclaus, 2006).

tic, it would be very difficult to distinguish the effects of e.g. changed halogen loading and circulation changes.

As discussed above, the most important external factors that distinguish a future atmosphere from today's atmosphere are the SSTs, sea ice and the concentrations of radiatively active gases. For the re-initialisation of the dynamics with these variables we have chosen a spinup period of three years. Since the chemical initialisation of long-lived trace gases directly affected by climate change was scaled consistently with the prescribed surface concentrations, the spinup period of three years is sufficiently long enough for short-lived trace gases to adjust to the new chemical background.

\subsection{Solar and geomagnetic variability}

The model contains most mechanisms of solar variability that are known to influence the lower and middle atmosphere. This includes effects from solar shortwave flux variability on radiative heating and photolysis, $\mathrm{NO}_{\mathrm{x}}$ formation by Galactic Cosmic Rays, $\mathrm{HO}_{\mathrm{X}}$ and $\mathrm{NO}_{\mathrm{x}}$ production by Solar Proton Events, and $\mathrm{NO}_{\mathrm{x}}$ production in the mesosphere and lower thermosphere through energetic electron precipitation (EEP). As discussed in Sect. 1, the latter process can lead to $\mathrm{NO}_{\mathrm{x}}$ enhancements $\left(\mathrm{EEP} \mathrm{NO}_{\mathrm{x}}\right)$ that are transported down into the stratosphere. The model implementation of this process is described by Baumgaertner et al. (2009).

In order to explicitly eliminate the influence of variability in the solar shortwave flux and SSTs, the shortwave flux was kept constant and SSTs were repeated on a 12-month basis. Solar Proton Events were not included in the model simulations because of their sporadic occurrence. The EEP strength for production of $\mathrm{NO}_{\mathrm{x}}$ in the mesosphere and lower thermosphere was set to 2003 with repeating monthly $A_{p}$ values as input, shown in Fig. 2. The $A_{p}$ index is a commonly used measure of global geomagnetic activity and is derived from magnetic field component measurements at 13 subauroral 


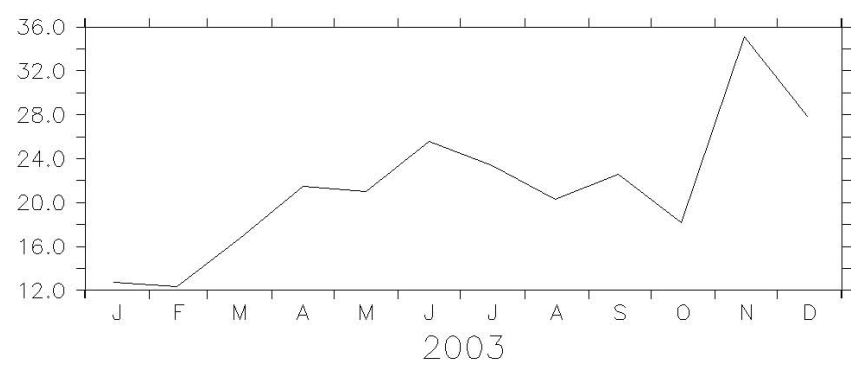

Fig. 2. Monthly average $A_{p}$ index for the year 2003 which is used as input for the EEP parametrisation.

geomagnetic observatories (Mayaud, 1980). The Southern Hemisphere winter 2003 experienced strong enhancements of EEP $\mathrm{NO}_{\mathrm{x}}$ (Funke et al., 2005; Randall et al., 2007), the May-July average $\mathrm{A}_{p}$ value of 23.1 exceeds that of all other years since 1958 except for 1991. The Halloween storm period from October to December 2003, relevant for the Northern Hemisphere winter, was characterised by even stronger geomagnetic activity. These large perturbations, which represent a "worst case" scenario, will make it possible to identify most clearly the effects focused on in this study. A further advantage of using $\mathrm{A}_{p}$ values from the year 2003 is that in Baumgaertner et al. (2009) the parameterisation of EEP $\mathrm{NO}_{\mathrm{x}}$ in the EMAC model was evaluated with a focus on the year 2003, which had been chosen because on the one hand, exceptionally high geomagnetic activity prevailed, and on the other hand high-resolution data was available from MIPAS/ENVISAT making a thorough evaluation possible.

\section{Results}

In order to evaluate the effects of climate change on the extent and the properties of EEP $\mathrm{NO}_{\mathrm{x}}$ enhancements, several simulations have to be performed and compared. We cannot simply compare two simulations, one for present day conditions and one for the year 2100, to analyse these effects. This is because in the simulation for the year 2100 climate change has affected the mean state of the atmosphere such that the induced EEP $\mathrm{NO}_{\mathrm{x}}$ changes are difficult to distinguish from other changes in the $\mathrm{NO}_{\mathrm{x}}$ and ozone distributions. Therefore, four simulations were carried out:

Simulation S-PRESENT-EEP. Model setup as described in Sect. 2.2. The EEP $\mathrm{NO}_{\mathrm{x}}$ source submodel was switched on.

Simulation S-PRESENT. As S-PRESENT-EEP but with the EEP $\mathrm{NO}_{\mathrm{x}}$ source submodel switched off.

Simulation S-Y2100-EEP. Model setup as described in Sect. 2.3 for year 2100 conditions. The EEP $\mathrm{NO}_{\mathrm{x}}$ source submodel was switched on.

Simulation S-Y2100. As S-Y2100-EEP but with the EEP $\mathrm{NO}_{\mathrm{x}}$ source submodel switched off.

Atmos. Chem. Phys., 10, 9647-9656, 2010

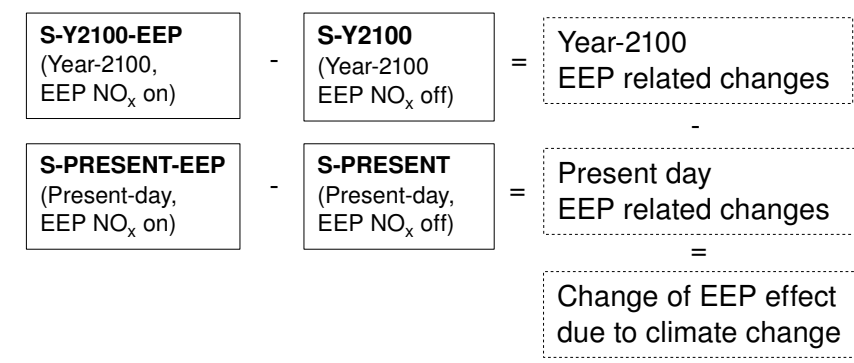

Fig. 3. Overview of the performed simulations and the performed processing.

The simulations S-PRESENT and S-Y2100 were integrated for a spin-up period of three years as discussed above. The resulting model states were used as the starting point for the four simulations described above. Each of these simulations was performed for nine model years.

To obtain the climate-change induced EEP $\mathrm{NO}_{\mathrm{x}}$ changes the following procedure is adopted, which is independent of the quantity of interest, i.e. $\mathrm{NO}_{\mathrm{x}}$ or ozone: In a first step the basic EEP related changes are calculated separately for both year- 2100 conditions and present conditions. Then, the result obtained for present day is subtracted from the year2100 result, yielding only the changes in EEP effects due to climate change. Note that this could include a BDC acceleration, but also temperature and background ozone mixing ratio changes, and it is difficult with the available set of simulations to distinguish these effects. This will be discussed in more detail below. A diagram of the processing procedure is presented in Fig. 3.

Since the model setup similar to the one used here has been evaluated extensively in several studies (Jöckel et al., 2006; Lelieveld et al., 2007; Brühl et al., 2007; Baumgaertner et al., 2009), we do not present an evaluation of the model. However, an evaluation of the circulation changes in the year2100 simulations is required. In the following, we analyse the changes in the zonal mean zonal wind as well as the trace gas distribution of $\mathrm{CO}$ with respect to the present day simulation.

Figure 4 depicts the climatological changes in zonal mean zonal wind for June-September in the Southern Hemisphere, hereafter referred to as SH winter (Fig. 4 left), and for December-March in the Northern Hemisphere, hereafter referred to as $\mathrm{NH}$ winter (Fig. 4 right). A paired t-test of the null hypothesis that data in the difference $\left(\mathrm{U}^{\mathrm{S}-\mathrm{Y} 2100}\right.$ $\mathrm{U}^{\mathrm{S}-\mathrm{PRESENT}}$ ) are a random sample from a normal distribution with mean 0 was performed. Areas, where the test fails at the $1 \%$ significance level, i.e. where the changes are statistically significant, are shaded. In both the $\mathrm{SH}$ and $\mathrm{NH}$ winters a strengthening of the subtropical westerly jets by $10 \mathrm{~m} / \mathrm{s}$ is found, consistent with the results of e.g. McLandress and Shepherd (2009). While there is hardly any response in the stratosphere at latitudes poleward of $70^{\circ} \mathrm{S}$ and $70^{\circ} \mathrm{N}$, in the 

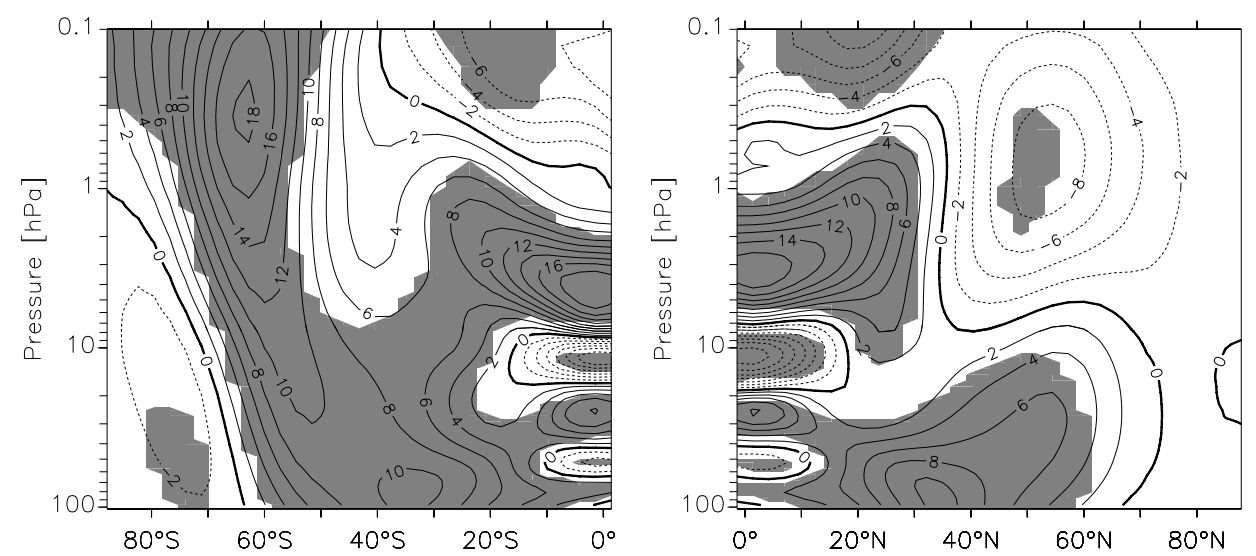

Fig. 4. Climatological change of SH winter (June-September, left) and NH winter (December-March, right) zonal mean zonal wind (m/s) in the year 2100 with respect to present day conditions $\left(\mathrm{U}^{\mathrm{S}-\mathrm{Y} 2100}-\mathrm{U}^{\mathrm{S}-\mathrm{PRESENT}}\right)$. Shaded areas indicate statistical significance at the $1 \%$ level.
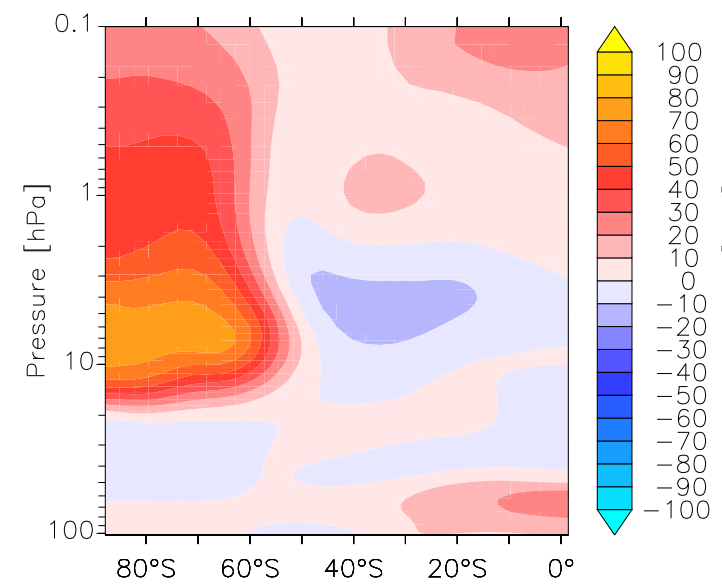

Fig. 5. Same as Fig. 4 but for CO mixing ratios (\%).

$\mathrm{SH}$ it is evident that the polar vortex strength has increased by up to $18 \mathrm{~m} / \mathrm{s}$. This is likely to reduce the strength of horizontal mixing of air across the vortex boundary, allowing less exchange of air between mid- and high latitudes. EEP $\mathrm{NO}_{\mathrm{x}}$ dilution is therefore likely to decrease, potentially leading to stronger EEP $\mathrm{NO}_{\mathrm{x}}$ effect in the year 2100. This will be discussed in detail below.

In the Northern Hemisphere, the situation appears to be reversed. In the upper stratosphere and lower mesosphere the polar vortex has weakened by $10 \mathrm{~m} / \mathrm{s}$. Note, however, that only for a very limited height/latitude region this change is significant, which results from the large intrinsic variability in the Northern Hemisphere polar middle atmosphere. Therefore, conclusions drawn from this region can only be tentative and longer simulations will be needed to study this effect on a sound statistical basis. For the short simulations presented here, the overall weakening of the vortex will on average lead to an increased mixing of air between mid and

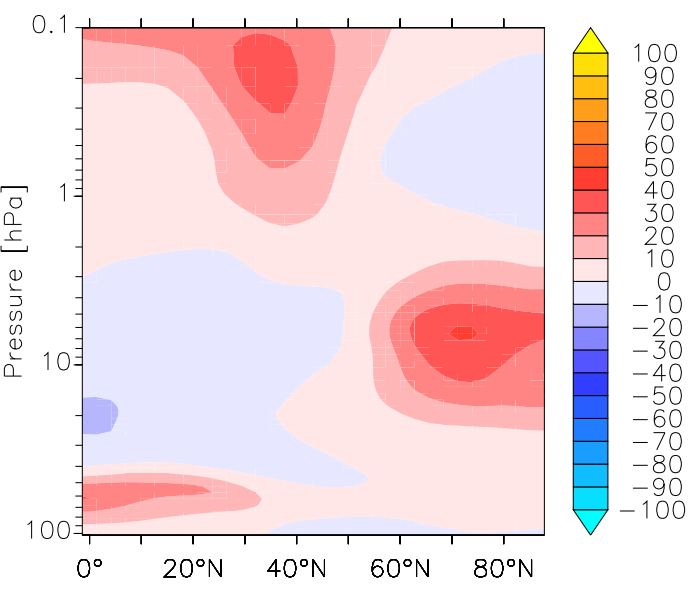

high latitudes, which will likely have consequences on the dilution of EEP $\mathrm{NO}_{\mathrm{x}}$.

The changes of the mean zonal wind at low latitudes are related to phase changes of the QBO. Due to the fact that only nine years are available for the analysis, no attempt is made to separate the results according to the phase of the QBO. This will be subject of future work.

Properties of CO (carbon monoxide) as a tracer for transport are described in Minschwaner et al. (2010). Its main characteristic is a continuously increasing volume mixing ratio from the tropopause to the thermosphere, thus, local enhancements of $\mathrm{CO}$ are a result of downward transport of air. Fig. 5 depicts the climatological changes of $\mathrm{CO}$ in $\mathrm{SH}$ (left) and $\mathrm{NH}$ (right) winter between the present day and year-2100 simulation in percent. It has to be noted that the overall increase of $\mathrm{CO}$ in the mesosphere of approximately $10 \%$ is likely a result of the increased production of $\mathrm{CO}$ from photolysis of $\mathrm{CO}_{2}$, which is more abundant in the S-Y2100 
simulation. For SH winter (left) enhancements of up to $80 \%$ are found in the high latitude middle atmosphere. Additional CO-rich air descends from higher altitudes, which is very likely a result of a modified circulation including the decrease of horizontal mixing by the strengthened vortex as discussed above. This can explain the 10-20\% decrease in $\mathrm{CO}$ in the mid-latitude stratosphere, and the corresponding increase at high latitudes. Since the high-latitude enhancements exceed the mid-latitude decrease, the enhancements are likely to be caused additionally by stronger downwelling, i.e., an accelerated BDC or mesospheric residual circulation.

During NH winter (Fig. 5, right) enhancements reach $60 \%$ in the high-latitude stratosphere. In the lower mesosphere, at mid-latitudes $\mathrm{CO}$ increases by up to $40 \%$, but at high latitudes $\mathrm{CO}$ mixing ratios actually decrease by up to $10 \%$. Because of the overall expected increase of $\mathrm{CO}$ by $\mathrm{CO}_{2}$ photolysis, this decrease would probably be even stronger without the increased photochemical production. Recalling that a weakened vortex, i.e., a more permeable region, was diagnosed from Fig. 4, this shift of $\mathrm{CO}$ from high to mid-latitudes can be explained by an increased horizontal mixing.

Having shown indications for the expected strengthening of the BDC as well as residual circulation changes in the mesosphere, we now analyse changes in $\mathrm{NO}_{\mathrm{x}}$ and ozone using the four simulations and the processing technique described above. Fig. 6 (left) depicts the climatological $\mathrm{NO}_{\mathrm{x}}$ change due to EEP $\left(\mathrm{NO}_{\mathrm{x}}^{\mathrm{S}-\mathrm{PRESENT}-\mathrm{EEP}}-\mathrm{NO}_{\mathrm{x}}^{\mathrm{S}-\mathrm{PRESENT}}\right)$ in the present day simulations, while Fig. 6 (middle) shows the same for the S-Y2100 simulations $\left(\mathrm{NO}_{\mathrm{x}}^{\mathrm{S}-\mathrm{Y} 2100-\mathrm{EEP}}\right.$ $\mathrm{NO}_{\mathrm{x}}^{\mathrm{S}-\mathrm{Y} 2100}$ ). The $5 \mathrm{nmol} / \mathrm{mol}$ contour line of the polar winter $\mathrm{NO}_{\mathrm{x}}$ enhancements that have descended from the mesosphere reach down to 9 and $10 \mathrm{hPa}$ at present day and in the year 2100 , respectively. The differences are more clearly identifiable if the present day changes are subtracted from the changes in the year 2100 (see also Fig. 3). The resulting change of EEP $\mathrm{NO}_{\mathrm{x}}$ due to climate change is shown in Fig. 6 (right). In the upper stratosphere there is a significant enhancement of up to $4.7 \mathrm{nmol} / \mathrm{mol}$, which is likely to be related to the circulation changes discussed above. A decrease of EEP $\mathrm{NO}_{\mathrm{x}}$ enhancements is found in the mesosphere north of $70^{\circ} \mathrm{S}$. This can probably be attributed to the decrease in horizontal mixing found above.

Analogously, Fig. 7 depicts results for the Northern Hemisphere. A decrease of EEP $\mathrm{NO}_{\mathrm{x}}$ enhancements is already evident when comparing the present day effects Fig. 7 (left) with the effects in the year 2100 (middle), but becomes even clearer in Fig. 7 (right), where the difference between the present day and year-2100 EEP effect is shown. A decrease of up to $25 \mathrm{nmol} / \mathrm{mol} \mathrm{NO}$ is found. Note, however, that this is only significant in the mesosphere, confirming that the variability in the Northern Hemisphere stratosphere in winter is large and only allows tentative conclusions to be drawn with the presented set of simulations. The decrease in the mesosphere is likely due to the weakened subsidence in the mesosphere found above and the increased meridional trans- port to lower latitudes by means of horizontal mixing. Note that several authors have recently discussed extreme meteorological conditions as a strong source for EEP $\mathrm{NO}_{\mathrm{x}}$ in the Northern Hemisphere (see e.g. Randall et al., 2006).

Finally, we present the effects of climate change and associated EEP $\mathrm{NO}_{\mathrm{x}}$ changes on ozone. Fig. 8 (left) shows the climatological difference of SH winter ozone mixing ratios between the S-Y2100 and the S-PRESENT simulation, so no EEP effect is considered here. A decrease of up to $0.5 \mu \mathrm{mol} / \mathrm{mol}$ is found in the tropical and subtropical lower stratosphere. These changes are consistent with a strengthening of the BDC and similar changes have been reported by $\mathrm{Li}$ et al. (2009), see their Fig. 2, who compared differences between 2060-2069 and 1975-1984. In the upper stratosphere, centred around $40^{\circ}$, ozone increased by up to $1.6 \mu \mathrm{mol} / \mathrm{mol}$, also similar to the results from Li et al. (2009). This is due to the increase of greenhouse gas concentrations, which leads to a cooling of the stratosphere (not shown, see e.g. Jonsson et al., 2004), which in turn slows down the temperature dependent photochemical ozone loss reactions (e.g. Barnett et al., 1975; Haigh and Pyle, 1982).

Figure 8 (middle) also depicts the ozone change in the year 2100 compared to present day, but including the EEP effect $\left(\mathrm{O}_{3}^{\mathrm{S}-\mathrm{Y} 2100-\text { EEP }}-\mathrm{O}_{3}^{\text {S-PRESENT-EEP }}\right)$. In contrast to Fig. 8 (left) the enhancement in the upper stratosphere at high southern latitudes is smaller. As for $\mathrm{NO}_{\mathrm{x}}$, the change of the EEP effect due to climate change can be evaluated quantitatively with the processing shown in Fig. 3. This is shown in Fig. 8 (right), which displays a high-latitude decrease of ozone exceeding $0.4 \mu \mathrm{mol} / \mathrm{mol}$, approximately reflecting the $\mathrm{NO}_{\mathrm{x}}$ changes found in Fig. 6 (right) in areas where sunlight and thus atomic oxygen is present, which allows the catalytic destruction of ozone to proceed. Overall it can be concluded that in the Southern Hemisphere the EEP $\mathrm{NO}_{\mathrm{x}}$ effect on ozone in the presented climate change scenario is approximately compensated by the increase of ozone caused by the climate change induced stratospheric cooling.

During NH winter the overall ozone enhancements in the upper stratosphere discussed above (Fig. 8, left) are also present, as shown in Fig. 9 (left). In the EEP $\mathrm{NO}_{\mathrm{x}}$ simulations, Fig. 9 (middle), ozone enhancements at high latitudes are even stronger than without the EEP $\mathrm{NO}_{\mathrm{x}}$. Again, Fig. 9 (right) shows the difference in analogy to the analysis for the Southern Hemisphere. Significant enhancements are found in the upper stratosphere and in the lower stratosphere exceeding $0.4 \mu \mathrm{mol} / \mathrm{mol}$. Since there were no significant $\mathrm{NO}_{\mathrm{x}}$ changes found below approximately $3 \mathrm{hPa}$, only the upper stratospheric enhancements can be directly attributed to the decrease of $\mathrm{NO}_{\mathrm{x}}$ seen in Fig. 7 (right). However, the low significance of the circulation changes (Fig. 4, right) means that these results are to be treated with care. 

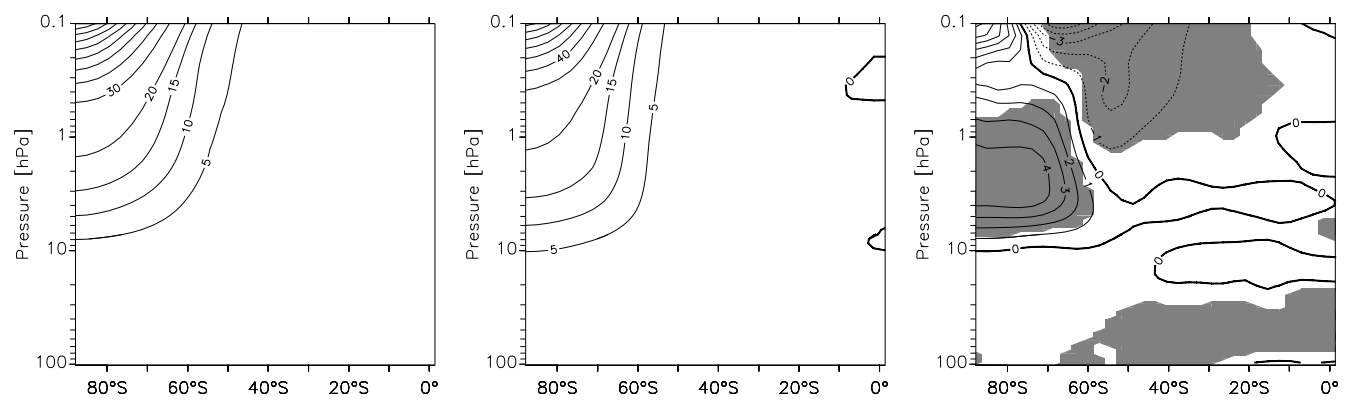

Fig. 6. EEP related changes of $\mathrm{NO}_{\mathrm{x}}$ in the present day $\left(\mathrm{NO}_{\mathrm{x}}^{\mathrm{S}-\mathrm{PRESENT}-\mathrm{EEP}}-\mathrm{NO}_{\mathrm{x}}^{\mathrm{S}-\mathrm{PRESENT}}\right.$, left) and year-2100 (NO${ }_{\mathrm{x}}^{\mathrm{S}-\mathrm{Y} 2100-\mathrm{EEP}}-$ $\mathrm{NO}_{\mathrm{x}}^{\mathrm{S}-\mathrm{Y} 2100}$, middle) simulations during $\mathrm{SH}$ winter. Contour lines show 5, 10, 15, 20, 30, 40, ...nmol/mol. Right: Change of EEP effect on $\mathrm{NO}_{\mathrm{x}}$ due to climate change induced circulation changes (difference between left and middle panel). The shaded area indicates statistical significance at the $1 \%$ level.
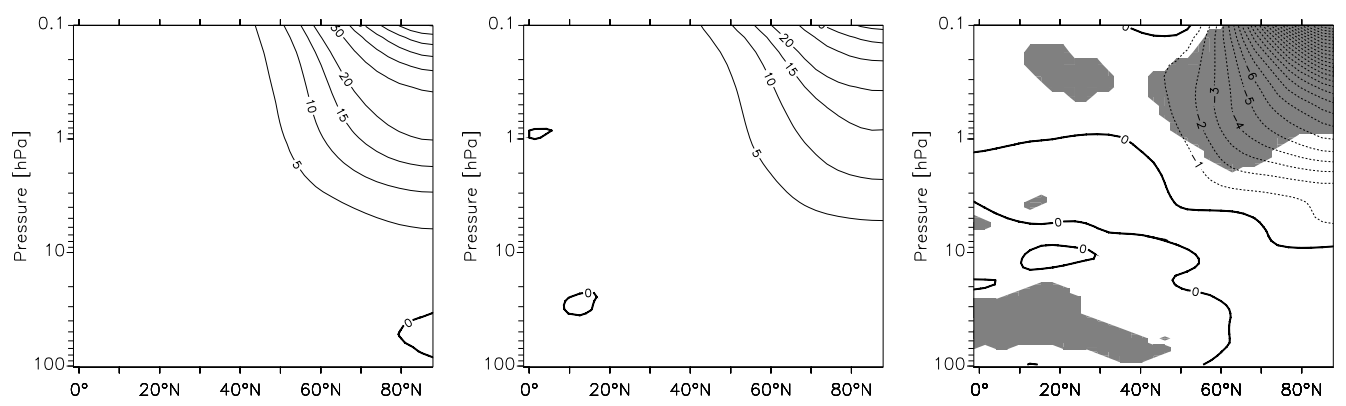

Fig. 7. As Fig. 6 but for the Northern Hemisphere.

\section{Conclusions}

As predicted by other model simulations (e.g. Butchart and Scaife, 2001), climate change leads to a stronger BDC in the presented EMAC simulations. Additionally, the strength of the residual circulation in the mesosphere is modified. In the Southern Hemisphere, the circulation changes and associated changes in horizontal mixing lead to a stronger downward transport of EEP $\mathrm{NO}_{\mathrm{x}}$ in the polar winter stratosphere, yielding a surplus of up to $4.7 \mathrm{nmol} / \mathrm{mol}$ in the upper stratosphere. Note that it is difficult to distinguish between changes in downwelling and mixing changes, but if we assume that the model captures the dynamics in this region correctly, under present and future conditions, this effect is contained in the simulations and therefore does not adversely affect the results. Quantification of such dilution and therefore a more accurate attribution of EEP effect changes is subject to future work.

The EEP $\mathrm{NO}_{\mathrm{x}}$ enhancements in turn cause some additional ozone loss of up to $0.4 \mu \mathrm{mol} / \mathrm{mol}$ in this area. However, the ozone loss is approximately compensated for by upper stratosphere ozone enhancements in the year 2100. Two processes related to climate change lead to this effect. First, a strengthened BDC also transports more low- and mid-latitude ozone to the polar area. Second, cooling of the stratosphere due to enhanced greenhouse gas concentrations leads to slower photochemical ozone loss reactions, globally enhancing ozone mixing ratios in the upper stratosphere.

In the Northern Hemisphere, a weaker mesospheric residual circulation and associated increase in horizontal mixing lead to less $\mathrm{NO}_{\mathrm{x}}$ entering the stratosphere. Therefore, the impact of EEP $\mathrm{NO}_{\mathrm{x}}$ on ozone is weaker than in the present day simulations, yielding up to $0.4 \mu \mathrm{mol} / \mathrm{mol}$ more ozone in the year 2100. Together with the expected increase of ozone from the BDC strengthening and the slower photochemical loss an additional $1.5 \mu \mathrm{mol} / \mathrm{mol}$ of ozone are found.

Note that the BDC acceleration has not been experimentally confirmed yet. Equally, measurements of the mesospheric residual circulation over the past three decades do not yet give an unambiguous picture of long-term trends. Extracting information on circulation changes due to greenhouse-gas related climate change from measurements is particularly challenging because of CFC-related ozone depletion, which could also cause changes in the residual circulation.

To date, changes in the mesosphere and lower thermosphere (MLT) circulation due to climate change have not been as thoroughly investigated as BDC changes. The current version of EMAC does not fully capture the MLT region, 

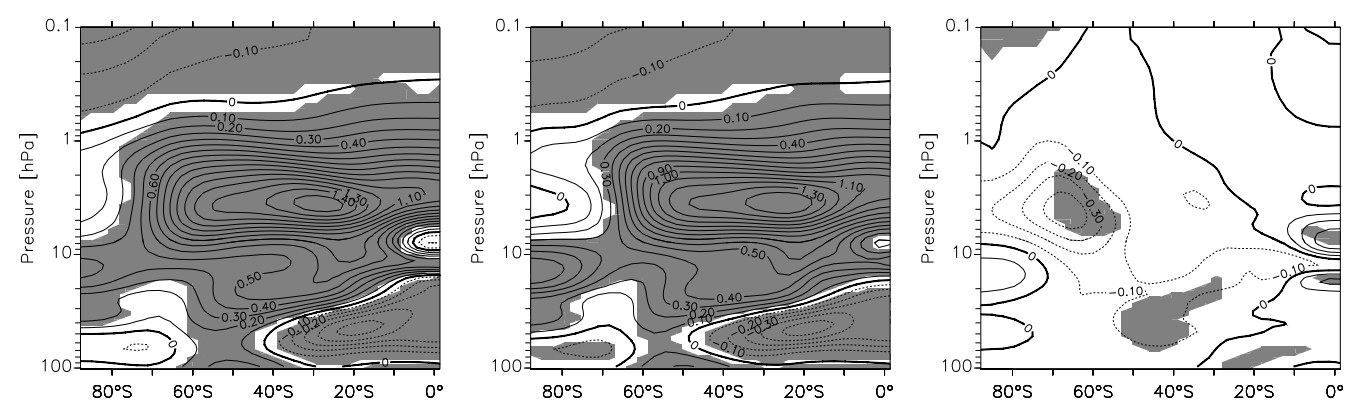

Fig. 8. Effect of climate change on ozone without EEP $\left(\mathrm{O}_{3}^{\mathrm{S}-\mathrm{Y} 2100}-\mathrm{O}_{3}^{\mathrm{S}-\mathrm{PRESENT}}\right.$, left $)$ and with EEP $\left(\mathrm{O}_{3}^{\mathrm{S}-\mathrm{Y} 2100-\mathrm{EEP}}-\right.$

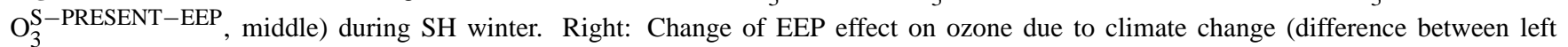
and middle panel). Units are $\mu \mathrm{mol} / \mathrm{mol}$. The shaded area indicates statistical significance at the $1 \%$ level.
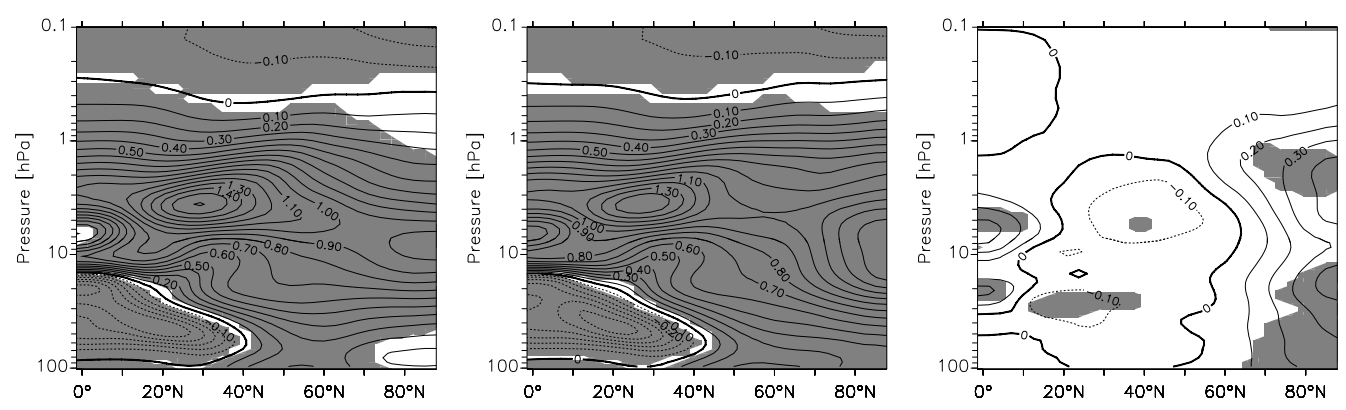

Fig. 9. Same as Fig. 8 but for NH winter.

so there is significant uncertainty towards the MLT circulation changes. Development of a whole atmosphere model with a more complete representation of the MLT is underway; this will include the middle and upper atmosphere model CMAT2 (UCL London, see e.g Yiğit et al., 2009) into MESSy allowing for a better representation of upper atmospheric $\mathrm{NO}_{\mathrm{x}}$ and thus make is possible to much more accurately study EEP $\mathrm{NO}_{\mathrm{x}}$ transport and effects.

\section{Appendix A}

\section{List of employed MESSy submodels:}

- CLOUD (large scale condensation, based on ECHAM5 subroutines),

- CONVECT (convection parametrisation, see Tost et al., 2006b),

- CVTRANS (convective tracer transport, see Tost et al., 2010),

- DRYDEP (dry deposition of gas phase species and aerosols, see Kerkweg et al., 2006a),

- H2O (consistent feedback of the chemically modified water vapour to the specific humidity of the base model),
- JVAL (photolysis rate calculations, based on Landgraf and Crutzen, 1998),

- LNOX (lightning $\mathrm{NO}_{\mathrm{x}}$ production, see Tost et al., 2007),

- MECCA (atmospheric chemistry submodel, see Sander et al., 2005),

- MSBM (polar stratospheric clouds, see Jöckel et al., 2010),

- OFFLEM and ONLEM (offline emission and online calculated emission of trace gases, see Kerkweg et al., 2006b),

- RAD4ALL (radiative calculations, based on ECHAM5 subroutines),

- SCAV (scavenging and liquid phase chemistry in clouds and precipitation, see Tost et al., 2006a),

- SEDI (particle sedimentation, see Kerkweg et al., 2006a),

- SPACENOX $\left(\mathrm{NO}_{\mathrm{x}}\right.$ production by Energetic electron precipitation, see Baumgaertner et al., 2009),

- TNUDGE (Newtonian relaxation of long-lived trace gases at the surface, see Kerkweg et al., 2006b),

- TROPOP (diagnostics submodel). 


\section{Supplement related to this article is available online at: http://www.atmos-chem-phys.net/10/9647/2010/ acp-10-9647-2010-supplement.zip.}

Acknowledgements. We thank all MESSy developers for their contributions and help. This research was funded by the TIES project within the DFG SPP 1176 CAWSES. The Ferret program (http://www.ferret.noaa.gov) from NOAA's Pacific Marine Environmental Laboratory was used for creating some of the graphics in this paper. The model simulations were performed on the POWER-6 computer at the DKRZ.

The service charges for this open access publication

have been covered by the Max Planck Society.

Edited by: F.-J. Lübken

\section{References}

Barnett, J. J., Houghton, J. T., and Pyle, J. A.: The temperature dependence of the ozone concentration near the stratopause, Q. J. Roy. Meteor. Soc., 101, 245-257, doi:10.1002/qj.49710142808, 1975.

Baumgaertner, A. J. G., McDonald, A. J., Fraser, G. J., and Plank, G. E.: Long-term observations of mean winds and tides in the upper mesosphere and lower thermosphere above Scott Base, Antarctica, J. Atmos. Sol-Terr. Phy., 67, 1480-1496, doi: 10.1016/j.jastp.2005.07.018, 2005.

Baumgaertner, A. J. G., Jöckel, P., and Brühl, C.: Energetic particle precipitation in ECHAM5/MESSy1 - Part 1: Downward transport of upper atmospheric $\mathrm{NO}_{x}$ produced by low energy electrons, Atmos. Chem. Phys., 9, 2729-2740, doi:10.5194/ acp-9-2729-2009, 2009.

Brasseur, G. P. and Solomon, S.: Aeronomy of the Middle Atmosphere: Chemistry and Physics of the Stratosphere and Mesosphere, Springer, third edn., 2005.

Brühl, C., Steil, B., Stiller, G., Funke, B., and Jöckel, P.: Nitrogen compounds and ozone in the stratosphere: comparison of MIPAS satellite data with the chemistry climate model ECHAM5/MESSy1, Atmos. Chem. Phys., 7, 5585-5598, doi: 10.5194/acp-7-5585-2007, 2007.

Butchart, N. and Scaife, A. A.: Removal of chlorofluorocarbons by increased mass exchange between the stratosphere and troposphere in a changing climate, Nature, 410, 799-802, 2001.

Butchart, N., Scaife, A. A., Bourqui, M., de Grandpré, J., Hare, S. H. E., Kettleborough, J., Langematz, U., Manzini, E., Sassi, F., Shibata, K., Shindell, D., and Sigmond, M.: Simulations of anthropogenic change in the strength of the Brewer Dobson circulation, Clim. Dynam., 27, 727-741, doi:10.1007/ s00382-006-0162-4, 2006.

Butchart, N., Cionni, I., Eyring, V., Shepherd, T. G., Waugh, D. W., Akiyoshi, H., Austin, J., Brühl, C., Chipperfield, M. P., Cordero, E., Dameris, M., Deckert, R., Dhomse, S., Frith, S. M., Garcia, R. R., Gettelman, A., Giorgetta, M. A., Kinnison, D. E., Li, F., Mancini, E., McLandress, C., Pawson, S., Pitari, G., Plummer, D. A., Rozanov, E., Sassi, F., Scinocca, J. F., Shibata, K., Steil, B., and Tian, W.: Chemistry-climate model simulations of $21 \mathrm{st}$ century stratospheric climate and circulation changes, J. Climate, doi:10.1175/2010JCLI3404.12010.
Callis, L. B., Natarajan, M., Lambeth, J. D., and Baker, D. N.: Solar - atmospheric coupling by electrons (SOLACE). 2. Calculated stratospheric effects of precipitating electrons, 1979-1988., J. Geophys. Res., 103, 28421-28438, doi:10.1029/98JD02407, 1998.

Clilverd, M. A., Rodger, C. J., and Ulich, T.: The importance of atmospheric precipitation in storm-time relativistic electron flux drop outs, Geophys. Res. Lett., 33, L01 102, doi:10.1029/ 2005GL024661, 2006.

Deckert, R. and Dameris, M.: Higher tropical SSTs strengthen the tropical upwelling via deep convection, Geophys. Res. Lett., 35, L10813, doi:10.1029/2008GL033719, 2008.

Enfield, D. B.: El Nino, past and present, Rev. Geophys., 27, 159_ 187, doi:10.1029/RG027i001p00159, 1989.

Engel, A., Möbius, T., Bönisch, H., Schmidt, U., Heinz, R., Levin, I., Atlas, E., Aoki, S., Nakazawa, T., Sugawara, S., Moore, F., Hurst, D., Elkins, J., Schauffler, S., Andrews, A., and Boering, K.: Age of stratospheric air unchanged within uncertainties over the past 30 years, Nat. Geosci., 3, 28-31, doi:10.1038/ngeo388, 2009.

Funke, B., López-Puertas, M., Gil-López, S., von Clarmann, T., Stiller, G. P., Fischer, H., and Kellmann, S.: Downward transport of upper atmospheric $\mathrm{NO}_{x}$ into the polar stratosphere and lower mesosphere during the Antarctic 2003 and Arctic 2002/2003 winters, J. Geophys. Res., 110, D24308, doi:10.1029/ 2005JD006463, 2005.

Garcia, R. R. and Randel, W. J.: Acceleration of the Brewer-Dobson circulation due to increases in greenhouse gases, J. Atmos. Sci., 65, 2731-2739, doi:10.1029/2006JD008306, 2008.

Garny, H., Dameris, M., and Stenke, A.: Impact of prescribed SSTs on climatologies and long-term trends in CCM simulations, Atmos. Chem. Phys., 9, 6017-6031, 2009,

http://www.atmos-chem-phys.net/9/6017/2009/.

Haigh, J. D. and Pyle, J. A.: Ozone perturbation experiments in a two-dimensional circulation model, Q. J. Roy. Meteor. Soc., 108, 551-574, doi:10.1256/smsqj.45704, 1982.

Harrison, D. E. and Larkin, N. K.: El Niño-Southern Oscillation sea surface temperature and wind anomalies, 1946-1993, Rev. Geophys., 36, 353-400, doi:10.1029/98RG00715, 1998.

IPCC: IPCC Fourth Assessment Report: Climate Change 2007, Cambridge University Press, Cambridge, 2007.

Jackman, C. H., Marsh, D. R., Vitt, F. M., Garcia, R. R., Fleming, E. L., Labow, G. J., Randall, C. E., López-Puertas, M., Funke, B., von Clarmann, T., and Stiller, G. P.: Short- and medium-term atmospheric constituent effects of very large solar proton events, Atmos. Chem. Phys., 8, 765-785, doi:10.5194/acp-8-765-2008, 2008.

Jöckel, P., Tost, H., Pozzer, A., Brühl, C., Buchholz, J., Ganzeveld, L., Hoor, P., Kerkweg, A., Lawrence, M. G., Sander, R., Steil, B., Stiller, G., Tanarhte, M., Taraborrelli, D., van Aardenne, J., and Lelieveld, J.: The atmospheric chemistry general circulation model ECHAM5/MESSy 1: consistent simulation of ozone from the surface to the mesosphere, Atmos. Chem. Phys., 6, 50675104, doi:10.5194/acp-6-5067-2006, 2006.

Jöckel, P., Kerkweg, A., Pozzer, A., Sander, R., Tost, H., Riede, H., Baumgaertner, A., Gromov, S., and Kern, B.: Development cycle 2 of the Modular Earth Submodel System (MESSy2), Geosci Model Dev. Discuss., 3, 1423-1501, doi:10.5194/gmdd-3-14232010, 2010. 
Jonsson, A. I., de Grandpré, J., Fomichev, V. I., McConnell, J. C., and Beagley, S. R.: Doubled $\mathrm{CO}_{2}$-induced cooling in the middle atmosphere: Photochemical analysis of the ozone radiative feedback, J. Geophys. Res., 109, D24103, doi:10.1029/ 2004JD005093, 2004.

Jungclaus, J.: IPCC-AR4 MPI-ECHAM5_T63L31 MPIOM_GR1.5L40 SRESA2 run no.3: ocean monthly mean values MPImet/MaD Germany. World Data Center for Climat, CERA-DB "OM-GR1.5L40_EH5-T63L31_A2_3_MM", 2006.

Kerkweg, A., Buchholz, J., Ganzeveld, L., Pozzer, A., Tost, H., and Jöckel, P.: Technical Note: An implementation of the dry removal processes DRY DEPosition and SEDImentation in the Modular Earth Submodel System (MESSy), Atmos. Chem. Phys., 6, 4617-4632, doi:10.5194/acp-6-4617-2006, 2006a.

Kerkweg, A., Sander, R., Tost, H., and Jöckel, P.: Technical note: Implementation of prescribed (OFFLEM), calculated (ONLEM), and pseudo-emissions (TNUDGE) of chemical species in the Modular Earth Submodel System (MESSy), Atmos. Chem. Phys., 6, 3603-3609, doi:10.5194/acp-6-3603-2006, $2006 \mathrm{~b}$.

Keuer, D., Hoffmann, P., Singer, W., and Bremer, J.: Longterm variations of the mesospheric wind field at mid-latitudes, Ann. Geophys., 25, 1779-1790, 2007.

Landgraf, J. and Crutzen, P. J.: An Efficient Method for Online Calculations of Photolysis and Heating Rates., J. Atmos. Sci., 55, 863-878, doi:10.1175/1520-0469(1998)055, 1998.

Lelieveld, J., Brühl, C., Jöckel, P., Steil, B., Crutzen, P. J., Fischer, H., Giorgetta, M. A., Hoor, P., Lawrence, M. G., Sausen, R., and Tost, H.: Stratospheric dryness: model simulations and satellite observations, Atmos. Chem. Phys., 7, 1313-1332, doi:10.5194/ acp-7-1313-2007, 2007.

Li, F., Stolarski, R. S., and Newman, P. A.: Stratospheric ozone in the post-CFC era, Atmos. Chem. Phys., 9, 2207-2213, doi: 10.5194/acp-6-2207-2009, 2009.

Marsland, S. J., Haak, H., Jungclaus, J. H., Latif, M., and Röske, F.: The Max-Planck-Institute global ocean/sea ice model with orthogonal curvilinear coordinates, Ocean Model., 5, 91-127, 2003.

Mayaud, P. N.: Derivation, Meaning, and Use of Geomagnetic Indices, Geophysical Monograph 22, Am. Geophys. Union, Washington DC, USA, 1980.

McLandress, C. and Shepherd, T. G.: Simulated Anthropogenic Changes in the Brewer-Dobson Circulation, Including Its Extension to High Latitudes, J. Climate, 22, 1516-1540, doi: 10.1175/2008JCLI2679.1, 2009.

Minschwaner, K., Manney, G. L., Livesey, N. J., Pumphrey, H. C., Pickett, H. M., Froidevaux, L., Lambert, A., Schwartz, M. J., Bernath, P. F., Walker, K. A., and Boone, C. D.: The photochemistry of carbon monoxide in the stratosphere and mesosphere evaluated from observations by the Microwave Limb Sounder on the Aura satellite, J. Geophys. Res., 115, D13303, doi:10.1029/2009JD012654, 2010.

Müller, W. and Roeckner, E.: ENSO teleconnections in projections of future climate in ECHAM5/MPI-OM, Clim. Dynam., 31, 533-549, 2008.
Nakicenovic, N., Alcamo, J., Davis, G., de Vries, B., Fenhann, B., Gaffin, S., Gregory K., Grübler, A., Jung, T. Y., Kram, T., La Rovere, E. L., Michaelis, E. L., Mori, S., Morita, T., Pepper, W., Pitcher, H., Price, L., Raihi, K., Roehrl, A., Rogner, H.-H., Sankovski, A., Schlesinger, M., Shukla, P., Smith, S., Swart, R., van Rooijen, S., Victor, N., and Dadi, Z.: IPCC Special Report on Emissions Scenarios, Cambridge University Press, UK and New York, NY, USA, 2000.

Randall, C. E., Harvey, V. L., Singleton, C. S., Bernath, P. F., Boone, C. D., and Kozyra, J. U.: Enhanced $\mathrm{NO}_{x}$ in 2006 linked to strong upper stratospheric Arctic vortex, Geophys. Res. Lett., 33, L18811, doi:10.1029/2006GL027160, 2006.

Randall, C. E., Harvey, V. L., Singleton, C. S., Bailey, S. M., Bernath, P. F., Codrescu, M., Nakajima, H., and Russell, J. M.: Energetic particle precipitation effects on the Southern Hemisphere stratosphere in 1992-2005, J. Geophys. Res., 112, D08308, doi:10.1029/2006JD007696, 2007.

Roeckner, E., Brokopf, R., Esch, M., Giorgetta, M., Hagemann, S., Kornblueh, L., Manzini, E., Schlese, U., and Schulzweida, U.: Sensitivity of Simulated Climate to Horizontal and Vertical Resolution in the ECHAM5 Atmosphere Model, J. Climate, 19, 3771, doi:10.1175/JCLI3824.1, 2006.

Sander, R., Kerkweg, A., Jöckel, P., and Lelieveld, J.: Technical note: The new comprehensive atmospheric chemistry module MECCA, Atmos. Chem. Phys., 5, 445-450, doi:10.5194/ acp-5-445-2005, 2005.

Schmidt, H., Brasseur, G. P., Charron, M., Manzini, E., Giorgetta, M. A., Diehl, T., Fomichev, V. I., Kinnison, D., Marsh, D., and Walters, S.: The HAMMONIA Chemistry Climate Model: Sensitivity of the Mesopause Region to the 11-Year Solar Cycle and $\mathrm{CO}_{2}$ Doubling, J. Climate, 19, 3903-3931, doi: 10.1175/JCLI3829.1, 2006.

Tost, H., Jöckel, P., Kerkweg, A., Sander, R., and Lelieveld, J.: Technical note: A new comprehensive SCAVenging submodel for global atmospheric chemistry modelling, Atmos. Chem. Phys., 6, 565-574, doi:10.5194/acp-6-565-2006, 2006 a.

Tost, H., Jöckel, P., and Lelieveld, J.: Influence of different convection parameterisations in a GCM, Atmos. Chem. Phys., 6, 54755493, doi:10.5194/acp-6-5475-2006, 2006b.

Tost, H., Jöckel, P., and Lelieveld, J.: Lightning and convection parameterisations - uncertainties in global modelling, Atmos. Chem. Phys., 7, 4553-4568, doi:10.5194/acp-7-4553-2007, 2007.

Tost, H., Lawrence, M. G., Brühl, C., Jöckel, P., The Gabriel Team, and The Scout-O3-Darwin/Active Team: Uncertainties in atmospheric chemistry modelling due to convection parameterisations and subsequent scavenging, Atmos. Chem. Phys., 10, 19311951, doi:10.5194/acp-10-1931-2010, 2010.

Yiğit, E., Medvedev, A. S., Aylward, A. D., Hartogh, P., and Harris, M. J.: Modeling the effects of gravity wave momentum deposition on the general circulation above the turbopause, J. Geophys. Res., 114, D07101, doi:10.1029/2008JD011132, 2009. 